\title{
ANALISIS DAMPAK DESENTRALISASI PENDIDIKAN DAN RELEVANSI SCHOOL BASED MANAGEMENT
}

\author{
Maisyanah \\ IAIN Kudus \\ Mayaarifin88@gmail.com
}

\begin{abstract}
Abstrak
Artikel ini menjelaskan bagaimana system pendidikan yang awalnya sentralisasi menjadi desentralisasi. Setiap perubahan tentu saja berkonsekuensi (berdampak) baik positif maupun negatif, tidak terkecuali pada sistem pendidikan. Penelitian ini merupakan kajian literatur, sumber primer yang digunakan adalah kebijakan pemerintah yang dituangkan pada undang-undang, dan untuk sumper primernya diambil dari sumber-sumber yang relevan guna menganalisis secara kritis dampak dari kebijakan tersebut. Hasil dari penelitian ini ada beberapa poin, yaitu (1) kebijkan yang digulirkan memiliki tujuan yang sangat ideal (2) ketidak siapan daerah dalam menerima perubahan (3) munculya raja-raja kecil di setiap daerah karena merasa memiliki kekuasaan penuh dalam mengelola daerahnya masing-masing (4) Sikap merasa menguasai memunculkan KKN (korupsi, kolusi dan nepotisme).
\end{abstract}

Kata Kunci: Desentralisasi Pendidikan, Manajemen Berbasis Sekolah, PAI

\begin{abstract}
Abstrack
This article explains how the education system that was originally centralized became decentralized. Every change of course has consequences (impacts) both positive and negative, not least in the education system. This research is a literature review, the primary sources used are government policies as outlined in the law, and for the primary sumper taken from relevant sources to critically analyze the impact of the policy. The results of this study are several points, namely (1) the policies that are rolled out have a very ideal goal (2) regional unpreparedness in accepting change (3) the emergence of small kings in each region because they feel they have full power in managing their respective regions each (4) attitude of feeling mastered raises KKN (corruption, collusion and nepotism).
\end{abstract}

Keywords: Decentralization of Education, School Based Management, PAI 


\section{A. PENDAhuluan}

Sejak runtuhnya pemerintahan Orde Baru menjadi Reformasi pada tahun ditetapkan Undang-Undang tentang otonomi. Dengan ditetapkannya undang- undang No. 32 dan 33 tahun 2004 tentang otonomi daerah menurut pembangunan pendidikan dioptimalkan di daerah. Selanjutnya peran bupati dan walikota diharapkan lebih serius dalam melaksanakan otonomi pendidikan dengan mengacu pada empat argumen pokok dalam membuat kebijakan pendidikan, yakni: peningkatan mutu, efisiensi keuangan, efisiensi administrasi, dan yang terakhir adalah perluasan/ perawatan. Dengan demikian semua aspek mulai dari ekonomi, pendidikan diserahkan kepada pemerintah daerah (Irene Astuti D, 2011 : 19-21). Selanjutnya peran bupati dan walikota diharapkan lebih serius dalam melaksanakan otonomi pendidikan dengan mengacu pada empat argumen pokok dalam mmebuat kebijakan pendidikan, yakni: peningkatan mutu, efisiensi keuangan, efisiensi administrasi, dan perluasan/pemerataan.

Dengan adanya desentralisasi pendidikan akan memperkuat pemerrintah daerah membangun kapital sosial pada pemerintah daerah. Karena penerapan desentralisasi pendidikan di Indonesia diperkuat dengan adanya Undang-Undang No. 22 tahun 1999 yang menekankan bahwa wewenang paling besar untuk sektor pendidikan sejak pendidikan pra sekolah sampai pendidikan menengah atas adalah urusan pemerintah kabupaten atau kota. Undang-Undang tersebut diperkuat lagi dengan munculnya Undang-Undang No. 20 Tahun 2003 tentang Sistem Pendidikan Nasional mengenai kewajiban orang tua untuk memberikan pendidikan dasar bagi anaknya (pasal 7 ayat 2). Selanjutnya, kewajiban bagi masyarakat memberikan dukungan sumber daya dalam menyelenggarakan pendidikan (pasal 9). Demikian juga tentang pendanaan pendidikan menjadi tanggung jawab bersama pemerintah, pemerintah daerah dan masyarakat (pasal 46 ayat 1). Dalam konteks inilah pendidikan di daerah benar-benar memberikan dasar yang cukup bagi daerah untuk lebih memberdayakan dalam arti lebih fungsional, memiliki fleksibilitas yang tinggi, dan tidak hanya sekedar menjadi retorika.

Seiring ditetapkannya undang-undang tentang otonomi daerah, maka pemerintah daerah juga memberikan kebijakan baru terhadap tiap-tiap lembaga pendidikan atau sekolah untuk mengelola secara mandiri dan profesional. 
School Based Management (SBM) adalah salah satu bentuk implementasi dari ditetapkannya Undang-Undang otonomi daerah. Dengan harapan kebijakan tersebut sekolah mampu mengatur dirinya secara otonom, tetapi dalam prosesnya pihak sekolah tidak akan mampu melaksanakan SBM secara optimal tanpa mendapatkan dukungan dari masyarakat dan orang tua siswa, meskipun pada kenyataannya saat ini keinginan atau keharusan tersebut belum terealisasi secara maksimal.

Melalui desentralisasi pendidikan, pemerintah berharap meningkatkan partisipasi masyarakat dalam meningkatkan mutu pendidikan. Ada kenyataanya dirubahnya pendidikan dari yang terpusat menuju ke daerah juga tidak begitu saja berjalan mulus. Dengan pernyataan yang demikian kemudia timbul pertanyaan, Mengapa harus desentralisasi? Bagaimana implementasi undang-undang otonomi daerah jika direlevansikan dengan MBS? Apa saja kendala yang dihadapi pemerintah pusat maupun daerah dalam mewujudkan undang-undang tersebut?

Bryant and White mendefinisikan desentralisasi adalah penekanan terhadap konsekuensi dari penyerahan wewenang untuk mengambil keputusan dan pengendalian tugas-tugas ketatanegaraan oleh badan-badan otonom daerah dalam rangka pemberdayaan potensi lokal. (Yoyon Bahtiar Iriyanto, 2011 : 67)

Desentralisasi juga merupakan salah satu badan lokal, jika badan lokal diberikan kewenangan sekaligus tanggung jawab mengelola sumber daya, maka kemampuan badan lokal untuk mengembangkan otoritasnya akan meningkat, dan apabila pemerintah lokal tersebut semata-mata ditugaskan untuk mengikuti kebijakan dari unit di tingkat pusat, maka kreatifitas unit lokal tersebut sangat terbatas.

Tresna berpendapat desentralisasi yaitu pemberian kekuasaan dari atas ke bawah dalam rangka kepegawaian, guna kelancaran pekerjaan semata-mata untuk mewujudkan asas demokrasi pemerintahan negara.

Secara etimologis, istilah desentaralisasi berasal dari bahasa latin "de" artinya lepas dan "centrum" yang berarti pusat, sehingga bisa diartikan lepas dari pusat. (Arif Rahman,, 2010: 129).

Dari beberapa pengertian di atas, penulis menyimpulkan, bahwasannya desentralisasi adalah penyerahan kewenangan dari pemerintah pusat kepada pemerintah daerah untuk menemukan dan mengelola potensi yang ada di daerah masing-masing, namun tidak sepenuhnya terlepas dari kontrol pemerintah pusat. 


\section{B. PEMBAHASAN}

Produk Kebijakan Desentralisasi Pendidikan

Undang-Undang RI nomor 32 tahun 2004 tentang Pemerintahan Daerah, pada pasal- I disebutkan bahwa "desentralisasi adalah penyerahan wewenang pemerintah oleh pemerintah pusat kepada daerah otonomi untuk mengatur dan mengurus urusan pemerintah dalam sistem negara kesatuan RI". (Undang-Undang RI dalam Arif Rahman, 2010: 130).

Desentralisasi dipilih karena sesuai dengan asas demokrasi. Desentralisasi pendidikan merupakan perubahan paradigma yang awalnya adalah sentaralistik, dan ini adalah konsekuensi dari ditetapkannya Undang-Undang tentang pemerintah otonomi daerah nomor 22 tahun 1999. Pemerintah mengambil kebijakan ini dengan pertimbangan agar pemerintah daerah sepenuhnya bertanggung jawab untuk mengelola pendidikan di daerahnya masing- masing.

Pada masa orde baru pendidikan sifatnya secara holistik sangat sentralis, diyakini atau tidak, menejemen yang sentralis akan menyebabkan kebijakan seragam yang tidak mampu mewadahi segala perbedaan, atau heterogenitas kepentingan setiap daerah, sekolah, dan peserta didik. Hal ini kemudian akan mematikan partisipasi masyarakat dalam proses pendidikan, serta mendorong terjadinya pemborosan dan kebocoran alokasi anggaran pendidikan.

Oleh karena itu, penguasa reformasi berupaya memformulasikan arah kebijakan pembangunan pendidikan dalam Garis-Garis Besar Haluan Negara (19991994), yaitu sebagai berikut: Mengupayakan perluasan dan pemerataan kesempatan memperoleh pendidikan yang bermutu tinggi bagi seluruh bagi seluruh rakyat Indonesia, menuju terciptanya manusia Indonesia yang berkualitas tinggi, dengan peningkatan anggaran pendidikan secara berarti.

Meningkatkan kemampuan akademis dan profesional, serta meningkatkan jaminan kesejahteraan tenaga pendidikan, sehingga tenaga pendidikan mampu berfungsi secara optimal, terutama dalam peningkatan pendidikan watak dan budi pekerti (sekarang lebih sering disebut dengan pendidikan karakter), agar dapat mengembalikan wibawa lembaga dan tenaga kependidikan.

Melakukan pembaruan sistem pendidikan, termasuk pembaruan kurikulum, berupa diversifikasi kurikulum untuk melayani keberagaman peserta didik, 
penyusunan kurikulum yang berlaku nasional dan lokal sesuai dengan kepentingan tepat, serta diversifikasi jenis pendidikan secara profesional.

Memberdayakan lembaga pendidikan, baik sekolah maupun luar sekolah, sebagai pusat pembudayaan nilai, sikap dan kemampuan serta meningkatkan partisipasi keluarga dan masyarakat yang didukung oleh sarana dan prasarana yang memadai.

Meningkatkan kualitas lembaga pendidikan, baik yang diselenggarakan oleh pemerintah maupun masyarakat untuk memantapkan sistem pendidikan yang efektif dan efisien, dalam menghadapi perkembangan ilmu pengetahuan, teknologi dan seni. Mengembangkan kualitas sumber daya manusia sedini mungkin secara terarah, terpadu dan menyeluruh melalui berbagai upaya proaktif dan reaktif oleh oleh seluruh komponen bangsa, agar generasi muda dapat berkembang secara optimal, disertai dengan hak dukungan dan perlindungan sesuai dengan potensinya.

Meningkatkan penguasaan, perkembangan, dan pemanfaatan ilmu pengetahuan dan teknologi, temasuk teknologi bangsa sendiri dalam dunia usaha, termasuk usaha kecil, menengah, dan koperasi guna meningkatkan daya saing produk yang berbasis sumber daya lokal ( Muhammad Rifa'I, 2011: 264).

Sebetulnya niat pemerintah pusat ini sangatlah baik apabila pemerintah daerah bersedia melaksanakan program ini dengan biak pula. Dengan adanya desentralisasi, maka tenaga pengajar merupakan putra daerah yang dipilih oleh pemerintah daerah. Akan terasa berbeda ketika seseorang mengabdikan diri di daerahnya sendiri dan mengabdikan diri di daerah orang lain. Rasa tanggung jawab dan dedikasi yang tinggi akan cenderung lebih besar apabila seseorang berjuang untuk daerahnya sendiri.

Langkah pemerintah ini juga merupakan implementasi dari demokrasi pendidikan, yang awalnya terpusat sifatnya tidak lagi terpusat, dan pemerintah daerah diberikan kewenangan sekaligus tanggung jawab untuk meningkatkan kualitas pendidikan di daerahnya masing-masing. Terlepas apakah masyarakat di setiap daerah sudah siap untuk menerima perubahan tentang desentralisasi atau belum. Bryant and White berpendapat bahwa dalam praktik yang nyata, asas desentralisasi terdiri dari dua bentuk, yakni desentraslisasi administrasi, dan desentralisasi politik.

Desentralisasi administrasi adalah pelimpahan wewenang untuk melaksanakan tugas- tugas yang diberikan kepada pejabat pusat yang ditempatkan di tempat lokal. 
Para pejabat tersebut bekerja dalam batas-batas rencana dan sumber pembiayaan yang sudah ditentukan oleh pejabat di tingkat pusat, namun pejabat yang di tingkat lokal juga memilki keleluasaan, wewenang dan tanggung jawab tertentu dalam kebijakan pemberian pelayanan di tingkat lokal. Sedangkan desentralisasi politik yaitu pelimpahan wewenang pembuatan keputusan dan pengendalian tertentu terhadap sumber-sumber daya yang diberikan kepada badan-badan pemerintah regional maupun lokal (Yoyon Bahtiar Iriyanto, 2011: 68).

Ada beberapa alasan masyarakat merasa belum siap dengan perubahan sistem desentralisasi ini dikarenakan ada beberapa sebab, diantaranya SDM yang belum memadai, sarana dan prasarana yang belum lengkap, anggaran pendapatan asli daerah yang masih sangat rendah, psikologis masyarakatnya sendiri yang takut dengan perubahan dan pembaharuan (Sam M. Chan, 2010:4), Oleh sebab itu sangat diperlukan paradigma baru dalam menerapkan kebijakan di lingkungan otonom sekolah, dan manajemen berbasis sekolah adalah bentuk alternatif sekolah sebagai hasil dari desentralisasi dalam bidang pendidikan.

Kendala-Kendala Pemerintah Pusat dan Daerah Dalam Mewujudakan Desentralisasi Pendidikan Apapun kebijakan yang diambil oleh pemerintah selalu menemukan kendala dalam implementasinya. Karena bagaimaanpun kendala merupakan bagian dari proses terwujudnya suatu tujuan. Begitu pula ada beberapa kendala yang dihadapi oleh pemerintah pusat maupun daerah dalam mewujudkan desentralisasi pendidikan yang sesuai dengan tujuan awal, yaitu untuk mewujudkan mutu pendidikan yang lebih baik.

Adapun kendala-kendala yang dihadapi baik pemerintah pusat maupun daerah adalah sebagai berikut: Sumber Daya Manusia Dari Tiap-Tiap Daerah yang Belum Memadai Secara Merata. Berhubungan dengan kualiatas dan kuantitas, ada daerah tertentu yang masih sangat tertinggal dalam memahami dan menganalisis serta mengaplikasikan desentralisasi pendidikan ini. Demikian pula dengan kuantitas SDM, meskipun saat ini begitu banyak lulusan sarjana tetapi apabila faktor-faktor lain, seperti kompetensi guru tidak menunjang, jumlah lembaga pendidikan yang tidak sesuai dengan jumlah lulusan, justru ini yang akan menimbulkan masalah yang baru bagi pemerintah daerah maupun pemerintah pusat. Sarana dan Prasarana di Pemerintah Daerah yang Belum Memadai 
Hal ini terjadi di wilayah pemerintah daerah, yang awalnya daerah selalu diberi oleh pemerintah pusat dalam sarana dan prasarana. Dengan diberlakukannya desentralisasi pemerintah daerah memikirkan dan mendapatkan sarana dan prasarana secara mandiri. Bagi pemerintah yang pendapatan daerahnya baik, mungkin hal ini tidak menjadi hambatan yang berarti, tetapi bagaimana bagi pemerintah daerah yang belum? Keharusan untuk mandiri ini pasti sangatlah menyulitkan.

Anggaran pendapatan asli daerah tertentu yang masih sangat rendah, untuk biaya pembangunan masih ditunjang oleh pusat atau provinsi, atau bila memungkinkan, mereka dapat bekerja sama dengan daerah lain yang memiliki pendapatan asli daerah (PAD) yang lebih besar.

Secara Psikologis Mental Pemerintah Maupun Masyarakat Daerah Masih Belum Siap Bahkan Takut Terhadap Perubahan

Perubahan merupakan suatu kepastian, namu tidak semua orang memiliki pandangan dan sikap yang sama terhadap sebuah perubahan. Ketakutan terhadap perubahan desentralisasi membuat sebagian pemerintah daerah tidak siap secara mental menghadapi perubahan tersebut.

Dalam konteks ini kepentingan politik, kebijakan dan kebijaksanaan pemerintah pusat menjadi ujung tombak perubahan kearah perbaikan. Terlalu lama membiarkan masalah berlarut-larut, berpotensi menimbulkan sikap apatis dan antipati pihak-pihak yang berkepentingan di bidang pendidikan. Dunia pendidikan seharusnya bebas dari pengaruh dan kepentingan politik. Dunia pendidikan adalah dunia idealisme. Sedangkan dunia politik adalah dunia pragmatisme. Jika dunia pendidikan sudah dicemari kepentingan politik, maka lambat tapi pasti akan muncul generasigenarasi pragmatis dan opurtunis. Jadi sebaiknya harus segera lakukan kajian terhadap desentralisasi pendidikan di tingkat kabupaten.

Dampak yang Ditimbulkan Dari Desentralisasi Pendidikan Desentralisasi pendidikan memberikan kewenangan kepada pemerintah daerah untuk melakukan rekrutmen pegawai dan pejabat di bidang pendidikan. Akibatnya nuansa kolusi, korupsi, dan nepotisme (KKN) sangat kental terjadi. Karena, semakin sempit wilayah maka kekerabatan semakin dekat sehingga nepotisme tidak dapat dihindari. Pengangkatan kepala sekolah dan pejabat pendidikan strategis lainnya yang tidak dilakukan dengan profesional akan melahirkan figur tidak sesuai dengan harapan. Oleh karena itu sistem rekrutmen yang diwarnai KKN diyakini akan menghasilkan 
produk yang tidak berkualitas. Ketika pejabat yang berwenang mengambil kebijakan dalam bidang pendidikan tidak berkualitas dan tidak memahami pendidikan secara holistik, maka keputusan yang diambil cenderung tidak berdampak positif terhadap perkembangan dunia pendidikan.

Birokrasi administrasi kepegawaian dalam dunia pendidikan juga menjadi lebih panjang dan berbelit, akibat penerapan desentralisasi pendidikan. Mekanisme kenaikan pangkat harus melalui tahap-tahap yang lebih banyak. Kondisi ini melahirkan sistem yang tidak efektif dan efisien, karena memakan waktu, biaya, dan tenaga lebih banyak. Pengorbanan waktu, biaya, dan tenaga yang lebih banyak untuk pengurusan administrasi pendidikan dipastikan mengurangi pelayanan kepada siswa. Ide awal desentralisasi pendidikan sesungguhnya untuk efektivitas dan efisiensi birokrasi. Namun fakta di lapangan menunjukkan bahwa arogansi kekuasaan pemerintah daerah justru menyebabkan kontra produktif dengan ide tersebut.

Desentralisasi pendidikan ternyata juga berdampak negatif terhadap pembiayaan pendidikan. Terhambatnya penyaluran dana bantuan sekolah (BOS) patut diduga disebabkan adanya desentralisasi pembiayaan pendidikan. Penyaluran BOS yang harus mendapatkan persetujuan DPRD merupakan faktor penghambat utama. Mekanisme yang berbelit, mulai dari pengarahan sampai menunggu ketok palu DPRD memakan waktu, biaya, dan tenaga yang banyak. Sementara itu, sekolah sangat mendesak memerlukan dana itu untuk penyenggaraan pendidikan. Oleh karena itu sangat relevan dan signifikan jika desentralisasi pendidikan dikaji ulang demi efektivitas dan efisiensi penyelenggaraan pendidikan dalam rangka meningkatkan kualitas sumber daya manusia.

Kelebihan dan Kekurangan Desentralisasi Pendidikan. Kelebihan yang diperoleh dari desentralisasi apabila dilaksanakan secara optimal adalah Meningkatnya mutu pendidikan nasioanal. Dari segi politik disentralisasi dimaksudkan untuk kepentingan daerah maupun untuk mendukung politik dan kebijakan nasional melalui pembangunan proses demokrasi lapisan bawah. Dari segi manjemen, desentalisasi dapat meningkatkan efektifitas, efisiensi, dan akuntabilitas publik. Dari segi kultural, desentralisasi dimaksudkan untuk memperhatikan kekhususan, keistimewaan suatu daerah, seperti geografis, kondisi penduduk, perekonomian, dan kebudayaan. Dari segi segi pembangunan, desentralisasi dapat 
melancarkan formulasi dan implementasi program untuk meningkatkan kesejahteraan masyarakat.( Siti Irene Astuti Dwiningrum, 2011 : 7)

Desentralisasi sekilas akan terlihat menimbulkan persaingan, namun daya saing yang sehat. Daya saing yang sehat di dalam masyarakat bukanlah kemampuan untuk saling membunuh dan saling menyingkirkan satu dengan yang lain, tetapi di dalam rangka kerjasama yang semakin lama semakin meningkat mutunya. Selama ini guru diyakini sebagai sosok yang paling bertanggung jawab dalam mewujudkan tujuan pendidikan( Musaheri, 2007: 101). Menurut penulis hal itu dirasa tidak tepat. Karena kerjasama dalam meningkatkan mutu pendidikan adalah tanggung jawab semua kalangan, tidak terbatas hanya pada guru saja, atau pemerintah pusat saja, bukan juga pemerintah daerah saja, tetapi semua elemen masyarakat, baik pemerintah sebagai penetap kebijakan, guru, siswa dan bahkan orang tua. Dan dengan adanya kebijikan ini diharapkan kerjasama dari seluruh elemen masyarakat akan terwujud secara sinergis dan harmonis.

Sedangkan kekurangannya adalah kebijakan ini sangat memungkinkan menimbulkan jurang pemisah antara si kaya dan si miskin, ini sangat tergantung dari pendapatan asli daerah (PAD) masing-masing. Kekurangan lain yaitu desentralisasi memberikan peluang kekuasaan yang cukup kuat dan besar bagi para Kepala Dinas Pendidikan. Hal ini membuka peluang terciptanya raja-raja kecil di daerah, khususnya ketika kontrol pemerintah provinsi dan pusat tidak lagi berperan dalam pengambilan keputusan.

Produk Kebijakan School Based Management (SBM) atau Manajemen Berbasis Sekolah (MBS)

School Based Management (SBM) atau Manajemen Berbasis Sekolah (MBS) menurut konsep Tim Teknis BAPPENAS merupakan bentuk alternatif sekolah dalam program desentralisasi bdang pendidikan, yanng ditandai dengan adanya otonomi luas tingkat sekolah, partisipasi masyarakat yang tinggi dan dalam rangka kebijakan pendidikan nasional.

Begawan Nanang Fattah menyebut MBS sebagai wujud dari reformasi pendidikan, yang menginginkan adanya perubahan dari kondisi yang kurang baik menuju kondisi yang lebih baik dengan memberikan kewenangan (otoritas) kepada sekolah unutk memberdayakan dirinya. 
Manajemen Berbasis Sekolah pada prinsipnya menempatkan kewenangan yang bertumpu kepada sekolah dan masyarakat, menghindarkan format sentralisasi yang dapat menyebabkan hilangnya fungsi manajemen (Yoyon Bahtiar Iriyanto, 2011: 159). MBS berpotensi untuk meningkatkan partisipasi masyarakat serta jauh dari birokrasi yang sentralistik, pemerataan, efisiensi, serta manajemen yang bertumpu di tingkat sekolah, hal ini juga merupakan tujuan utama dari MBS (Amiruddin Siahaan, dkk, 2006: 5).

Sejalan dengan dimulainya otonomi daerah di kota dan kabupaten, maka pemerintah memberikan otonomi pendidikan ke sekolah dengan pelaksanaan manajemen berbasis sekolah, melalui undang-undang no. 20 tahun 2003 tentang sistem pendidikan nasional pasal 51 butir 1, yaitu: "Pengelolaan satuan pendidikan anak usia dini, pendidikan dasar, dan pendidikan menengah dilaksanakan berdasarkan pelayanan minimal dengan prinsip manajemen berbasis sekolah/madrasah". (Heri Suderadjat: 42).

Prinsip SBM, Amiruddin Siahaan, dkk, (2006:36) dalam buku manajemen pendidikan berbasis sekolah (MPBS), Sebagai tolak ukur dari keberhasilan implementasi manajemen pendidikan berbasis sekolah (MPBS) ada 16 indikator, yang meliputi:

- Efektifitas proses pembelajaran

- Kepemimpinan sekolah yang kuat

- Pengelolaan tenaga kependidikan yang efektif

- $\quad$ Sekolah memiliki budaya mutu

- $\quad$ Sekolah memiliki team work yang kompak, cerdas dan dinamis

- $\quad$ sekolah memiliki kemandirian

- $\quad$ partisipasi warga sekolah dan masyarakat tinggi

- $\quad$ sekolah memiliki transparansi

- $\quad$ sekolah memiliki kemauan untuk berubah, baik psikologis maupun fisik

- $\quad$ sekolah melakukan evaluasi dan perbaikan secara berkelanjutan

- $\quad$ sekolah responsif dan antisipasif terhadap kebutuhan

- $\quad$ sekolah memiliki akuntabilitas

- $\quad$ sekolah memiliki sustauntabilitas

- $\quad$ output adalah prestasi sekolah 
- $\quad$ penekanan angka drop-out

- dan kepuasan staf sesuai dengan tugas dan kewenangannya.

Problematika SBM, Menurut Amiruddin Siahaan, ada tiga permasalahan yang menghambat implementasi SBM. Dan hal ini juga skaligus menjadi kelemahan penerapan manajemen pendidikan. Yang pertama adalah implementasi MBS sifatnya hanya anjuran, sehingga sangat wajar apabila pelaksanaan di lapangan masih belum maksimal. Yang kedua, kontrol masyarakat belum memadai, khususnya orang tua peserta didik. Terutama di kalangan masyarakat non-perkotaan yang masih menganggap bahwa sekolah adalah satu-satunya lembaga yang paling bertanggung jawab atas keberhasilan pendidikan anak-anak mereka. Hal itu karena masyarakat, khususnya orang tua tadi belum mengetahui manajemen berbasis sekolah secara utuh, karena sebenarnya yang dimaksud dengan otonomi sekolah bukan berarti sekolah berjalan sendiri, melainkan harus ada kerjasama antara sekolah dan masyarakat setempat.

Ketiga adalah peran komite sekolah yang belum maksimal. Selama ini komite sekolah hanya dianggap sebagai alat kelengkapan semata tanpa memberikan bantuan yang bersifat signifikan terhadap kebutuhan sekolah. Problem yang sama, yaitu komite, atau sebagian anggota komite belum mengetahui secara utuh tentang hakikat SBM (Heri Suderadjat, 2005: 81-94)

\section{KESIMPULAN}

Desentralisasi bukanlah lawan dari sentralisasi. Dan otonomipun bukan lawan dari desentralisasi, hanya saja tugas, kepercayaan wewenang, dan tanggung jawablah yang menjadikan keduanya berbeda.

Implementasi dari desentralisasi pendidikan di indonesia saat ini menurut penulis sudah terlaksana, meskipun masih ada kekurangan yang merupakan bagian dari proses tercapainya tujuan dari desentralisasi pendidikan yang menjadi tujuan dari pendidikan nasional.

Peraturan atau istilah yang lebih halusnya kebijakan, seperti yang sudah di bahas di atas tentang desentralisasi dan SBM yang diberlakukan di lembaga formal memang penting untuk terapkan demi mewujudkan tujuan pendidikan di Indonesia. Namun yang tidak kalah penting dan yang sering terlupakan adalah pendidikan informal/pendidikan di lingkungan 
keluarga. Sebaik apapun manajemen yang diterapkan di sekolah, terkadang masih menyulitkan guru untuk mempengaruhi dan merubah perilaku "negatif” peserta didik.

Tujuan pendidikan tidak mungkin tercapai apabila berat sebelah, atau dengan kata lain tidak seimbang. Kunci yang mampu mewujudkan tujuan pendidikan di indonesia bukan hanya menjadi tanggung jawab pemerintah saja, melainkan ini adalah tanggung jawab dan kerjasama antara pemerintah, masayarakat dan elemen terkecil dan terpenting dalam mewujudkan pendidikan di Indonesia ini adalah keluarga. Semuanya harus mampu bertindak sebagai praktisi sekaligus mampu mengontrol secara bersama-sama dalam upaya meningkatkan kualitas pendidikan dan mencapai tujuan pendidikan baik secara mikro maupun secara makro. 
Maisyanah

\section{DAFTAR PUSTAKA}

Assegaf, Abd. Rachman, Aliran Pemikiran Pendidikan Islam, Jakarta: Rajawali Persada, 2013.

Astuti Dwiningrum, Siti Irene. Desentralisasi Dan Partisipasi Masyarakat

Dalam Pendidikan, Yogyakarta: Pustaka Pelajar, 2011.

Iriyanto, Yoyon Bahtiar. Kebijakan Pembaruan Pendidikan Konsep, Teori dan Model, Jakarta: PT Raja Grafindo Persada, 2011.

Mariana, Dede. Demokrasi dan Politik Desentralisasi, Yogyakarta: Graha Ilmu, 2008 .

M. Chan, Sam. Kebijakan Pendidikan Era Otonomi Daerah, Jakarta: PT Raja Grafindo Persada, 2010.

Musaheri. Pengantar Pendidikan , Yogyakarta: IRCiSoD, 2007.

Rahman, Arif. Education Policy In Decentralization Era, Yogyakarta: Pustaka Pelajar, 2010.

Rifa'i, Muhammad. Politik Pendidikan Nasional, Yogyakarta: Ar-Ruzz Media, 2011 .

Sejarah Pendidikan Nasional, Yogyakarta: Ar-Ruzz Media, 2011.

Sa’ud, Udin Syaefudin. Perencanaan Pendidikan, Bandung: Rosdakarya, 2009.

Siahaan, Amiruddin, dkk, Manajemen Pendidikan Berbasis Sekolah, Ciputat: Quantum Teaching, 2006.

Suderadjat, Heri, Manajemen Peningkatan Mutu Berbasis Sekolah (MPMBS), Bandung: CV Cipta Cekas Grasika, 2005.

Tilaar, H.A.R. Kebijakan Pendidikan, Yogyakarta: Pustaka Pelajar, 2008.

Wibowo, Agus, Manajemen Pendidikan Karakter di Sekolah (konsep dan praktik implementasi), Yogyakarta: Pustaka Pelajar, 2013. 